\title{
TANGGUNG JAWAB PELAKU USAHA TERHADAP KERUGIAN KONSUMEN DALAM JUAL BELI KENDARAAN BERMOTOR (STUDI PT. HEROINTINUSA)
}

\author{
Agus Nurmansyah, Fakultas Hukum Universitas Udayana, \\ e-mail: goezur@gmail.com \\ A.A.Ketut Sukranatha, Fakultas Hukum Universitas Udayana, \\ e-mail: agung_sukranatha@unud.ac.id \\ doi: https://doi.org/10.24843/KS.2020.v08.i08.p10
}

\begin{abstract}
ABSTRAK
Tujuan dari penulisan jurnal ilmiah ini adalah untuk mengetahui bentuk-bentuk pelanggaran yang dilakukan oleh karyawan (PT. Herointinusa) yang merugikan konsumen dan mengetahui tentang tanggungjawab pelaku usaha (PT. Herointinusa) terhadap kerugian yang dialami oleh konsumen. Metode penelitian yang digunakan yaitu metode penelitian hukum empiris dengan menggunakan pendekatan perundang-undangan dan pendekatan fakta dan penggunaan sumber data yaitu sumber data primer dan sekunder yang kemudian dikaitkan dengan kenyataan di lapangan. Dari hasil penelitian yang dilakukan, Manajemen PT. Herointinusa bertanggung jawab penuh dengan memberikan sanksi yang tegas kepada oknum karyawan yang terbukti bersalah dan manajemen perusahaan juga bertanggungjawab terhadap kerugian yang diderita konsumen dengan cara non litigasi atau menyelesaikan sengketa di luar pengadilan dengan cara musyawarah atau meminta pertanggungjawaban langsung dalam bentuk ganti rugi kepada konsumen yang dirugikan.
\end{abstract}

Kata Kunci : Perlindungan, Tanggung jawab, Penyelesaian Hukum.

\begin{abstract}
The purpose of this scientific journal is to know the find out the forms of violations committed by employees (PT. Herointinusa) that are detrimental to consumers and to know about the responsibility of business actors (PT. Herointinusa) for losses suffered by consumers. The research method used is the empirical legal research method using the legislation approach and the fact approach and the use of data sources namely primary and secondary data sources which are then linked to reality on the ground. From the results of research conducted, the Management of PT. Herointinusa takes full responsibility by giving strict sanctions to unscrupulous employees and the company's management is also responsible for losses suffered by consumers by non-litigation or resolving disputes outside the court by deliberation or asking for direct liability in the form of compensation to consumers who are harmed.
\end{abstract}

Keywords: Protection, Liability, Legal Settlement.

\section{Pendahuluan}

\subsection{Latar Belakang}

Transportasi adalah kegiatan pemindahan manusia atau barang dari suatu tempat ke tempat lain. ${ }^{1}$ Dalam hal ini, pengangkutan mencakup beberapa aspek yang

1 Abbas, Salim. Manajemen Transportasi, (Jakarta, PT. Raja Grafindo Persada, 2000). 
sangat luas meliputi aspek sosial, aspek budaya, aspek politik dan pertahanan, aspek hukum, aspek teknik dan aspek ekonomi".2 "Secara umum transportasi dibagi menjadi 3 yaitu transportasi darat, transportasi laut, dan transportasi udara". ${ }^{3}$ Dari ketiga jenis transportasi tersebut, transportasi daratlah yang dominan digunakan, khususnya sepeda motor. Oleh karena itu kebutuhan akan sepeda motor sebagai alat transportasi sangatlah tinggi. Untuk memperoleh sepeda motor baru, konsumen bisa memilikinya dengan cara membeli secara cash ataupun credit. Namun sebelum itu, konsumen diwajibkan mengikuti proses-proses tertentu yang mana dalam hal ini lebih pada pendataan data konsumen (pembuatan STNK atau BPKB). Pendataan ini sangatlah penting dan sifatnya pribadi. Karena sifatnya yang sangat pribadi maka data ini tidak boleh diberikan ke sembarangan orang atau dalam hal ini butuh perlindungan. Perlindungan hukum adalah memberikan pengayoman kepada hak asasi manusia yang dirugikan orang lain dan perlindungan tersebut diberikan kepada masyarakat agar mereka dapat menikmati semua hak-hak yang diberikan oleh hukum". ${ }^{4}$ Tanggung jawab dalam bidang hukum (legal responsibility) dimaksudkan sebagai keterikatan terhadap ketentuan-ketantuan hukum. ${ }^{5}$ Oleh karena itu, PT. Herointinusa Honda yang mana dalam hal ini rekanan dari PT Astra Honda Motor (AHM) harus mengidentifikasi, memantau, dan mengendalikan kemungkinankemungkinan yang bisa terjadi dengan prinsip kehati-hatian.

Walaupun sudah menggunakan tahapan yang cukup dengan prinsip kehatihatian tetapi tidak menjadi jaminan bahwa di dalam proses berjalannya perusahaan ini tidak terjadi gangguan atau berjalan mulus, karena pada tahun 2013 pernah terjadi pelanggaran oleh oknum karyawan dengan cara memberikan data pribadi konsumen kepada kompetitor, yang mana mengakibatkan kerancuan data internal di dalam pengurusan surat-surat kendaraan (STNK dan BPKB) dan menurunkan pendapatan perusahaan serta merugikan konsumen dari segi waktu dan finansial (keuangan). Harapannya, dengan diadakan penelitian ini, kedepannya tidak akan terulang lagi hal-hal seperti ini dan PT. Herointinusa Honda tetap bisa eksis dalam hal penjualan sepeda motor Honda.

\subsection{Rumusan Masalah}

1. Bagaimanakah bentuk-bentuk pelanggaran yang dilakukan oleh karyawan PT. Herointinusa yang merugikan konsumen?

2. Bagaimanakah tanggungjawab pelaku usaha (PT. Herointinusa) terhadap kerugian yang dialami oleh konsumen?

\subsection{Tujuan Penelitian}

Penulisan artikel ini bertujuan untuk mengetahui tentang bentuk-bentuk pelanggaran yang dilakukan oleh karyawan PT. Herointinusa yang merugikan

\footnotetext{
Nasution, A. Manajemen Transportasi, (Jakarta, Ghalia Indonesia, 1996).

Abbas Salim , op.cit, 49.

4 Raharjo, Satjipto. "Penyelenggaraan Keadilan dalam Masyarakat yang sedang berubah." Jurnal masalah hukum 2, no. 3 (1993).

5 Kartika, I. Made Surya, and AA Sagung Wiratni Darmadi. "Tanggung Jawab Pelaku Usaha Periklanan dalam Memberikan Informasi yang Lengkap dan Benar." Jurnal Kertha Semaya 3, no. 04 (2016).
} 
konsumen serta untuk mengetahui tentang tanggungjawab pelaku usaha (PT. Herointinusa) terhadap kerugian yang dialami oleh konsumen.

\section{Metode Penelitian}

Metode penelitian yang digunakan di dalam penelitian ini ialah metode penelitian hukum empiris, dengan mempergunakan pendekatan perundangundangan, pendekatan fakta, dan analisis konsep hukum. sifat penelitian deskriptif. Data dan sumber data didapat dari data di lapangan dan kepustakaan, dengan teknik pengumpulan data wawancara, serta analisis data menggunakan analisis kualitatif.

\section{Hasil dan Pembahasan}

\subsection{Bentuk-Bentuk Pelanggaran yang Merugikan Konsumen}

Seorang karyawan bisa dikategorikan melanggar rahasia dagang jika memberi informasi tempat dia bekerja kepada perusahaan lain. ${ }^{6}$ Dalam prakteknya perjanjian tentang Rahasia Dagang merupakan hal yang vital. Hal ini ditunjukkan dengan betapa pentingya Rahasia Dagang yang juga merupakan aset perusahaan yang sangat mahal, karena dapat menjadi alat yang ampuh untuk bersaing dengan kompetitor. ${ }^{7}$ Membocorkan data pribadi konsumen tidak hanya merugikan perusahaan tetapi juga konsumen.

Pasal 1 Undang-Undang Nomor 8 tahun 1999 tentang Perlindungan Konsumen (selanjutnya disebut Undang-Undang Perlindungan Konsumen), menyatakan bahwa konsumen ialah setiap orang pemakai barang dan/atau jasa yang tersedia dalam masyarakat, baik bagi kepentingan diri sendiri, keluarga, orang lain maupun makhluk hidup lain dan tidak untuk diperdagangkan. Sedangkan dalam kamus hukum, pengertian konsumen ialah pihak yang mempergunakan atau memanfaatkan baik barang ataupun jasa, untuk kepentingan diri sendiri maupun untuk kepentingan orang lain. ${ }^{8}$ Transaksi elektronik ialah suatu transaksi perdagangan baik berupa penyebaran, pembelian, penjualan, pemasaran barang dan jasa dengan menggunakan media elektronik yang terhubung melalui internet. Transaksi ini sangat memungkinkan terjadinya pelanggaran hak-hak konsumen mengingat transaksi elektronik mempunyai ciri yang berbeda dengan transaksi konvensional. Untuk itu perlu adanya perlindungan hukum kepada konsumen dalam jual beli barang yang mengandung unsur penyalahgunaan keadaan yang dihubungkan dengan Undang-Undang Nomor 8 Tahun 1999 tentang Perlindungan Konsumen. Penyalahgunaan keadaan yang sering dilakukan oleh pihak pelaku usaha melanggar Pasal 4 Undang-Undang Perlindungan Konsumen tentang hak-hak konsumen. ${ }^{9}$ Dari hasil wawancara dan sebagaimana juga

6 Mahila, Syarifa. "Perlindungan Rahasia Dagang dalam Hubungannya dengan Perjanjian Kerja." Jurnal Ilmiah Universitas Batanghari Jambi 10, no. 3 (2017): 16-24.

7 Gerungan, Anastasia E. "Perlindungan Hukum terhadap Rahasia Dagang Ditinjau dari Aspek Hukum Perdata dan Pidana di Indonesia oleh: Anastasia E. Gerungan." Jurnal Hukum Unsrat 22, no. 5 (2016).

8 Erlinawati, Mira, and Widi Nugrahaningsih. "Implementasi Undang-undang Nomor 8 Tahun 1999 Tentang Perlindungan Konsumen terhadap Bisnis Online." Serambi Hukum 11, no. 01 (2017): 27-40.

9 Setyawati, Desy Ary, Dahlan Ali, and M. Nur Rasyid. "Perlindungan Bagi Hak Konsumen dan Tanggung Jawab Pelaku Usaha Dalam Perjanjian Transaksi Elektronik." Syiah Kuala Law Journal 1, no. 3 (2017): 46-64. 
telah diatur dalam Peraturan Perusahaan PT. Herointinusa, ada pelanggaran yang terjadi di PT. Herointinusa yang merugikan konsumen dan perusahaan diantaranya:

1. Melanggar Pasal 2 Ayat 5 Peraturan Perusahaan Herointinusa yang berbunyi : Setiap karyawan wajib menjaga rahasia Perusahaan dan atau sesuatu yang menurut sifatnya harus dirahasiakan.

2. Berdasarkan hasil wawancara dengan Bapak Ghandi, sebagai Manager Marketing di PT. Herointinusa Cabang Kartini, pada tanggal 3 Agustus 2019 menjelaskan bahwa, memberikan data pribadi konsumen kepada kompetitor (misal No HP, Nama Konsumen, Alamat) merupakan suatu pelanggaran. Seperti yang pernah terjadi dipertengahan tahun 2013, seorang oknum karyawan yang bernama Yunia (sales) memberikan data konsumen atas nama Bapak Wijaya ke showroom lain dengan imbalan mendapakan diskon lebih besar untuk mendapatkan keuntungan pribadi yang jelas dalam hal ini merugikan konsumen dan perusahaan.

3. Melanggar Pasal 2 Ayat 14 Peraturan Perusahaan Herointinusa yang berbunyi : Setiap karyawan wajib menjaga dan memelihara dengan baik milik/asset Perusahaan, melaporkan jika ditemukan hal-hal yang dapat membahayakan atau merugikan Perusahaan kepada Pimpinan.

4. Berdasarkan hasil wawancara dengan Bapak Bayu, sebagai HRD di PT. Herointinusa, pada tanggal 6 Agustus 2019 menjelaskan bahwa, oknum karyawan yang dalam hal ini masuk kategori sering membuat masalah harus segera diberikan sanksi yang tegas. Karena jika dipertahankan dapat memberikan dampak negatif bagi rekan kerja dan perusahaan.

5. Melanggar Pasal 9 Ayat 3 Peraturan Perusahaan Herointinusa yang berbunyi : Setiap karyawan wajib melakukan absensi kehadiran di tempat kerja setiap datang dan pulang kerja.

6. Berdasarkan hasil wawancara dengan Bapak Bayu, sebagai HRD di PT Herointinusa, pada tanggal 6 Agustus 2019 menjelaskan bahwa, karyawan harus disiplin terkait jam masuk dan pulang kerja karena disamping merugikan perusahaan terkait kurang efisien waktu kerja juga merugikan konsumen. Misal alasan datang terlambat dikarenakan macet, antar anak sekolah atau ban sepeda motor bocor.

7. Melanggar visi dan misi Peraturan Perusahaan Herointinusa yang berbunyi: memberikan layanan prima dan solusi yang bernilai tambah kepada seluruh konsumen.

8. Berdasarkan hasil wawancara dengan Ibu Kristin, sebagai Konsumen di PT. Herointinusa, pada tanggal 14 Agustus 2019 menjelaskan bahwa, ia pernah mengalami hal yang kurang nyaman terkait pelayanan disaat ingin membeli kendaraan yang di handle icha (sales). Merasa diacuhkan karena disaat transaksi jual beli belum selesai, sudah menghandle konsumen lain. Setelah diberikan penjelasan oleh Bapak Ghandi sebagai Manager Marketing untuk menyelesaikan dulu transaksinya baru boleh menghandle konsumen baru, akhirnya Ibu Kristin bisa kembali melanjutkan transaksinya.

9. Melanggar Pasal 2 Ayat 17 Peraturan Perusahaan Herointinusa yang berbunyi : Setiap karyawan wajib memakai pakaian kerja, memakai sepatu dan kartu tanda pengenal selama di lingkungan kerja sesuai dengan ketentuan yang ditetapkan oleh perusahaan. 
10. Berdasarkan hasil wawancara dengan Bapak Bayu, sebagai HRD di PT. Herointinusa, pada tanggal 6 Agustus 2019 menjelaskan bahwa, tindakan pelanggaran lainnya yang sering terjadi ialah tindakan indisipliner atau dalam hal ini melanggar peraturan yang berlaku, namun sifatnya masih relatif dapat dimaklumi.

Etika bisnis dalam perusahaan merupakan hal yang sangat vital. Perusahaan akan berhasil tidak hanya berlandaskan sikap dan management yang baik, tetapi juga mesti memiliki etika bisnis yang baik. Perusahaan yang menjunjung etika bisnis, pada hakekatnya termasuk perusahaan yang mempunyai tingkat kepuasan kerja yang tinggi, misal diskriminasi dalam sistem karir maupun gaji. Perlu diketahui, karyawan yang berkualitas ialah aset paling berharga bagi perusahaan. Oleh sebab itu, perusahaan harus semaksimal mungkin mempertahankan karyawannya. ${ }^{10}$

\subsection{Tanggungjawab Pelaku Usaha (PT. Herointinusa) terhadap Kerugian yang Dialami Konsumen}

Berdasarkan ketentuan Undang-Undang Perlindungan Konsumen di Indonesia tepatnya Pasal 28 UUPK, hal ini memberikan konsekuensi hukum bahwa pelaku usaha yang dapat membuktikan kerugian bukan merupakan kesalahannya terbebas dari tanggung jawab ganti kerugian. ${ }^{11}$ Pertanggungjawaban privat, sehubungannya dengan tanggung jawab pelaku usaha telah diatur didalam Undang-Undang No. 8 Tahun 1999 tentang Perlindungan Konsumen yaitu sebagai berikut: ${ }^{12}$

\section{Pasal 19:}

1) Pelaku usaha bertanggung jawab memberikan ganti rugi atas kerusakan, pencemaran, dan/atau kerugian konsumen akibat mengkonsumsi barang dan/atau jasa yang dihasilkan atau diperdagangkan.

2) Ganti rugi sebagaimana dimaksud pada ayat (1) dapat berupa pengembalian uang atau penggantian barang dan/atau jasa yang sejenis atau setara nilainya, atau perawatan kesehatan dan/atau pemberian santunan yang sesuai dengan ketentuan peraturan perundang-undangan yang berlaku.

3) Pemberian ganti rugi dilaksanakan dalam tenggang waktu 7 (tujuh) hari setelah tanggal transaksi.

4) Pemberian ganti rugi sebagaimana dimaksud pada ayat (1) dan ayat (2) tidak menghapuskan kemungkinan adanya tuntutan pidana berdasarkan pembuktian lebih lanjut mengenai adanya unsur kesalahan.

5) Ketentuan sebagaimana dimaksud pada ayat (1) dan ayat (2) tidak berlaku apabila pelaku usaha dapat membuktikan bahwa kesalahan tersebut merupakan kesalahan konsumen.

10 Hasoloan, Aswand. "Peranan Etika Bisnis dalam Perusahaan Bisnis." Warta Dharmawangsa 57 (2018).

11 Rumimper, Grace Joice SN. "Tanggung Jawab Pelaku Usaha Terhadap Konsumen Dalam Jual Beli Melalui Internet." Jurnal Hukum Unsrat 1, no. 3 (2013): 56-67.

12 Riung, Chrisai Marselino. "Tanggung Jawab Pelaku Usaha Terhadap Kerugian Konsumen Dalam Transaksi Melalui E-commerce." Lex Privatum 3, no. 2 (2015). 


\section{Pasal 22:}

"Pembuktian terhadap ada tidaknya unsur kesalahan dalam kasus pidana sebagaimana dimaksud dalam Pasal 19 ayat (4), Pasal 20, dan Pasal 21 merupakan beban dan tanggung jawab pelaku usaha tanpa menutup kemungkinan bagi jaksa untuk melakukan pembuktian".

\section{Pasal 23:}

"Pelaku usaha yang menolak dan/atau tidak memberi tanggapan dan/atau tidak memenuhi ganti rugi atas tuntutan konsumen sebagaimana dimaksud dalam Pasal 19 ayat (1), ayat (2), ayat (3), dan ayat (4), dapat digugat melalui badan penyelesaian sengketa konsumen atau mengajukan ke badan peradilan di tempat kedudukan konsumen".

\section{Pasal 25:}

1) Pelaku usaha yang memproduksi barang yang pemanfaatannya berkelanjutan dalam batas waktu sekurang-kurangnya 1 (satu) tahun wajib menyediakan suku cadang dan/atau fasilitas purna jual dan wajib memenuhi jaminan atau garansi sesuai dengan yang diperjanjikan.

2) Pelaku usaha sebagaimana dimaksud pada ayat (1) bertanggung jawab atas tuntutan ganti rugi dan/atau gugatan konsumen apabila pelaku usaha tersebut:

a. tidak menyediakan atau lalai menyediakan suku cadang dan/atau fasilitas perbaikan

b. tidak memenuhi atau gagal memenuhi jaminan atau garansi yang diperjanjikan.

\section{Pasal 26:}

"Pelaku usaha yang memperdagangkan jasa wajib memenuhi jaminan dan/atau garansi yang disepakati dan/atau yang diperjanjikan".

\section{Pasal 27 :}

Pelaku usaha yang memproduksi barang dibebaskan dan tanggung jawab atas kerugian yang diderita konsumen, apabila:

a. barang tersebut terbukti seharusnya tidak diedarkan atau tidak dimaksudkan untuk diedarkan.

b. cacat barang timbul pada kemudian hari.

c. cacat timbul akibat ditaatinya ketentuan mengenai kualifikasi barang; d. kelalaian yang diakibatkan oleh konsumen.

d. lewatnya jangka waktu penuntutan 4 (empat) tahun sejak barang dibeli atau lewat jangka waktu yang diperjanjikan

\section{Pasal 28:}

"Pembuktian terhadap ada tidaknya unsur kesalahan dalam gugatan ganti rugi sebagaimana dimaksud dalam Pasal 19, Pasal 22, dan Pasal 23 merupakan beban dan tanggung jawab pelaku usaha."

Berdasarkan isi ketentuan dari Pasal 19 ayat (1) di atas dapat diketahui bahwa tanggung jawab pelaku usaha meliputi:

1. Tanggung jawab ganti kerugian atas kerusakan; 
2. Tanggung jawab ganti kerugian atas pencemaran; dan

3. Tanggung jawab ganti kerugian atas kerugian konsumen. ${ }^{13}$

\section{Pasal 60:}

1) Badan Penyelesaian Sengketa Konsumen berwenang menjatuhkan sanksi administratif terhadap pelaku usaha yang melanggar Pasal 19 ayat (2) dan ayat (3), Pasal 20, Pasal 25, Pasal 26.

2) Sanksi administratif berupa penepatan ganti rugi paling banyak Rp 200.000.000,00 (dua ratus juta rupiah).

3) Tata cara penetapan sanksi administratif sebagaimana dimaksud pada ayat (1) diatur lebih lanjut dalam peraturan perundang- undangan. ${ }^{14}$

Dalam hal ini, hubungan hukum antara konsumen dengan pelaku usaha tidak menutup kemungkinan menimbulkan perselisihan atau sengketa konsumen. ${ }^{15}$ Berdasarkan hasil wawancara dengan Ibu Kristin, sebagai konsumen di PT. Herointinusa, pada tanggal 14 Agustus 2019 menjelaskan bahwa, ia pernah mengalami hal yang kurangnyaman terkait pelayanan disaat ingin membeli kendaraan yang di handle icha (sales). Merasa diacuhkan karena disaat transaksi jual beli belum selesai sudah menghandle konsumen lain. Setelah diberikan penjelasan oleh Bapak Ghandi sebagai Manager Marketing untuk menyelesaikan dulu transaksinya baru boleh menghandle konsumen baru, akhirnya Ibu Kristin bisa kembali melanjutkan transaksinya. Dalam hal ini, Ibu Kristin lebih memilih menyelesaikan sengketanya dengan cara non litigasi. Ia mengaku tidak ada niatan untuk melaporkan masalahnya ke BPSK karena takut memakan biaya dan waktu.

Berdasarkan hasil wawancara dengan Bapak Wijaya, sebagai konsumen di PT. Herointinusa, pada tanggal 3 Agustus 2019 menjelaskan bahwa ia juga pernah mengalami kerugian saat membeli kendaraan bermotor. Seperti yang terjadi dipertengahan tahun 2013, seorang oknum karyawan yang bernama Yunia (sales) memberikan data konsumen atas nama Bapak Wijaya ke showroom lain dengan imbalan mendapakan diskon lebih besar untuk mendapatkan keuntungan pribadi. Ia baru mengetahui dan merasa dirugikan ketika ia dijanjikan akan mendapat motor baru dalam waktu 1 bulan tetapi hingga waktunya, unit yang dijanjikan tidak kunjung tiba dan tidak ada penjelasan sehingga ia mencari informasi langsung ke PT Herointinusa. Hasilnya ada sales yang bernama Yunia bermain dengan kompetitor lain dan belum di pesankan di delaer tersebut. Terkait hal ini perusahaan selaku pihak yang bertanggungjawab langsung memberikan dua kebijakan, pertama untuk konsumen diberikan diskon lebih dari pembelian kendaraannya dan diberikan souvenir sebagai ganti kerugian sedangkan karyawan yang bermain (Yunia) dipecat secara tidak

13 Ahmadi Miru dan Sutarman Yodo. Hukum Perlindungan Konsumen, (Jakarta, PT. Raja Grafindo Persada, 2007).

14 Syahrizal, Abbas. Mediasi dalam Perspektif Hukum Syariah, Hukum Adat dan Hukum Nasional, (Jakarta, Kencana, 2011).

15 Celina, Tri Siwi Kristiyanti. Hukum Perlindungan Konsumen, (Jakarta, PT. Sinar Grafika, 2008). 
hormat. Dalam hal ini, Bapak Wijaya Kusuma lebih memilih menyelesaikan sengketanya dengan cara non litigasi. Ia bahkan tidak mengetahui adanya BPSK.

Begitu juga dengan hasil wawancara dengan Bapak Aziz dan Bapak Rudi, sebagai konsumen di PT. Herointinusa, pada tanggal 4 Agustus 2019 menjelaskan bahwa, mereka juga pernah mengalami kerugian saat membeli kendaraan bermotor. Disaat proses pembelian kendaraan baru konsumen merasa kurang diberikan penjelasan detail terkait apa saja yang didapat. Waktu melakukan proses service berkala pertama (I) seharusnya konsumen mendapatkan jasa service dan olie gratis namun saat service dikenakan pembayaran. Dan konsumen memprotes karena sepengetahuan mereka seharusnya service berkala pertama (I) tidak bayar. Setelah dilakukan penelusuran oleh Pak Komang sebagai kepala bengkel, bahwa ada kesalahan penyampaian dari Yoni selaku sales di PT. Herointinusa. Oleh sebab itu Ibu Atik sebagai General Manager langsung memberi kebijakan tetap memberikan jasa service dan olie gratis dan untuk Yoni selaku sales yang salah memberikan informasi, langsung diberikan sanksi ganti rugi biaya jasa service dan olie gratis akibat dari kelalaiannya. Bapak Aziz dan Bapak Rudi juga lebih memilih memilih menyelesaikan sengketanya dengan cara non litigasi. Ia bahkan mengaku tidak pernah mendengar adanya badan yang bertugas menyelesaikan sengketa konsumen.

\section{Kesimpulan}

Dari uraian pembahasan di atas dapat ditarik kesimpulan bahwa bentuk-bentuk pelanggaran yang dilakukan oleh karyawan yang merugikan konsumen dan perusahaan di PT. Herointinusa diantaranya oknum karyawan dengan sengaja memberikan data pribadi konsumen kepada kompetitor, sering membuat masalah, kurang disiplin terkait jam masuk dan pulang kerja, tidak memberikan pelayanan yang prima dan solusi yang bernilai tambah kepada konsumen, tidak memakai ID Card di saat jam kerja. Secara rinci, Undang-Undang Perlindungan Konsumen No. 8 Tahun 1999 sudah memberikan perlindungan yang cukup baik pada konsumen. Hal ini jelas terlihat dari cakupan materinya yang luas dan lebih memberikan perlindungan yang maksimal bagi konsumen. Salah satunya yaitu dengan mengatur tentang pembalikan beban pembuktian dalam membuktikan unsur kesalahan yang harus dibuktikan oleh pelaku usaha (Produsen), bukan oleh konsumen. Baik dalam perkara pidana maupun perkara perdata. Berdasarkan hasil penelitian, pihak Manajemen PT. Herointinusa bertanggungjawab penuh dengan memberikan sanksi yang tegas kepada oknum karyawan yang terbukti bersalah dan manajemen perusahaan juga bertanggungjawab terhadap kerugian yang diderita konsumen dengan cara non litigasi atau menyelesaikan sengketa di luar pengadilan dengan cara musyawarah atau memberikan pertanggungjawaban langsung dalam bentuk ganti rugi kepada konsumen yang dirugikan.

\section{Daftar Pustaka \\ Buku}

Abbas, Salim. Manajemen Transportasi, (Jakarta, PT. Raja Grafindo Persada, 2000).

Ahmadi Miru dan Sutarman Yodo. Hukum Perlindungan Konsumen, (Jakarta, PT. Raja Grafindo Persada, 2007). 
Celina, Tri Siwi Kristiyanti. Hukum Perlindungan Konsumen, (Jakarta, PT. Sinar Grafika, 2008).

Nasution, A. Manajemen Transportasi, (Jakarta, Ghalia Indonesia, 1996).

Syahrizal, Abbas. Mediasi dalam Perspektif Hukum Syariah, Hukum Adat dan Hukum Nasional, (Jakarta, Kencana, 2011).

\section{Jurnal}

Erlinawati, Mira, and Widi Nugrahaningsih. "Implementasi Undang-undang Nomor 8 Tahun 1999 Tentang Perlindungan Konsumen terhadap Bisnis Online." Serambi Hukum 11, no. 01 (2017): 27-40.

Gerungan, Anastasia E. "Perlindungan Hukum terhadap Rahasia Dagang Ditinjau dari Aspek Hukum Perdata dan Pidana di Indonesia oleh: Anastasia E. Gerungan." Jurnal Hukum Unsrat 22, no. 5 (2016).

Hasoloan, Aswand. "Peranan Etika Bisnis dalam Perusahaan Bisnis." Warta Dharmawangsa 57 (2018).

Kartika, I. Made Surya, and AA Sagung Wiratni Darmadi. "Tanggung Jawab Pelaku Usaha Periklanan dalam Memberikan Informasi yang Lengkap dan Benar." Jurnal Kertha Semaya 3, no. 04 (2016).

Mahila, Syarifa. "Perlindungan Rahasia Dagang dalam Hubungannya dengan Perjanjian Kerja." Jurnal Ilmiah Universitas Batanghari Jambi 10, no. 3 (2017): 1624.

Riung, Chrisai Marselino. "Tanggung Jawab Pelaku USAha Terhadap Kerugian Konsumen Dalam Transaksi Melalui E-commerce." Lex Privatum 3, no. 2 (2015).

Rumimper, Grace Joice SN. "Tanggung Jawab Pelaku Usaha Terhadap Konsumen Dalam Jual Beli Melalui Internet." Jurnal Hukum Unsrat 1, no. 3 (2013): 56-67.

Raharjo, Satjipto. "Penyelenggaraan Keadilan dalam Masyarakat yang sedang berubah." Jurnal masalah hukum 2, no. 3 (1993).

Setyawati, Desy Ary, Dahlan Ali, and M. Nur Rasyid. "Perlindungan Bagi Hak Konsumen dan Tanggung Jawab Pelaku Usaha Dalam Perjanjian Transaksi Elektronik." Syiah Kuala Law Journal 1, no. 3 (2017): 46-64.

\section{Peraturan perundang-undangan}

Indonesia, Undang-Undang Tentang Perlindungan Konsumen, Undang-Undang Nomor 8 Tahun 1999, Lembaran Negara Republik Indonesia Tahun 1999 Nomor 42, Tambahan Lembaran Negara Republik Indonesia Nomor 3821. 